\title{
Questionnaires, Parish Registers and Prize Competitions: The Zurich Physical Society's Sources and Methods for Surveying the Territory
}

\author{
Sarah Baumgartner
}

During the early modern period, Europeans not only began to "discover" and conquer the world, but they also showed a growing interest in the usefulness of knowing the natural resources of their home territory. ${ }^{1}$ This trend intensified in the second half of the 18th century, when rulers came to appreciate the importance of such knowledge and supported initiatives to survey their subject territories. At the same time, new methods of generating knowledge emerged. Besides, and in collaboration with, state administrations, different actors took part in such efforts, including individual researchers as well as associations. In addition, let us not forget those local informants whom the "experts" often resorted to and had to rely on.

In the Swiss city-state of Zurich, it was a private society, the "Physical Society," which took the first steps in this direction. In my article, I want to examine its motivation for doing so, as well as the methods it used and the theories that guided its activities. The focus will be on two cases where the society actively and systematically collected information: first, the censuses of the city's residents and, secondly, the Society's manifold efforts to gather information on the rural population and its subsistence strategies. Finally, this paper will show what the Society's new picture of Zurich and its territory looked like, and what conclusions the members drew from that. To begin with, however, let us provide some useful contextual information on the Society and the city where it was located.

Being, together with Bern, one of the political centres of the Old Swiss Confederacy, Zurich was a city-state with a "capital" of approximately 10,000

1 Alix Cooper, Inventing the Indigenous: Local Knowledge and Natural History in Early Modern Europe (Cambridge, New York: Cambridge University Press, 2007). 
inhabitants - or to be more precise about 2,ooo adult male "burghers" - ruling over a considerable territory with a population that by the end of the 18th century had risen from about 120,000 to 180,000 inhabitants. The town's constitution was essentially republican, but over the centuries, political power became more and more concentrated in the hands of a few rich families. ${ }^{2}$ Most of them owed their wealth to the export-oriented textile industry, a branch of business that sprang up in the 16th century. It was organised in the putting-out system, which meant that urban merchants - only the capital's burghers were entitled to exercise this activity - provided rural outworkers with the raw materials they would then process, and later picked up the finished goods for distribution. Hence, the putting-out industry not only strongly shaped the economic conditions and political power relations within the city, but also had far-reaching consequences for the countryside and its population. Workers earned a wage that, even when small, constituted a source of income independent of agriculture. Even poor, landless couples were now able to marry and to found families. In the second half of the 18th century, about one-third of Zurich's rural population was in some way or other occupied in this industry, spinning or weaving cotton, linen or silk. ${ }^{3}$ This trade formed the basis of Zurich's financial wealth, but was not risk-free. A considerable proportion of the rural population were without enough land to cover their own needs, and this made them more dependent on grain imports. Poor harvests could easily result in severe subsistence crises, which is what happened, for example, in the early 177os.

Besides its political and economic relevance, Zurich also became known as a cultural hotspot of Enlightenment Europe: indeed, the poet Johann Jacob Bodmer (1698-1783) and the theologian Johann Caspar Lavater (1741-1801) attracted visitors from all over the Continent. Zurich's citizens were interested in contemporary intellectual debate and began to get together in newly established "societies" to discuss the latest literature, as well as political ideas. This, of course, did not happen only in Zurich, but was quite a widespread phenomenon in that period. In the context of the so-called "society movement" of the Age of Enlightenment, all over Europe, a new type of social association was emerging. Although broad variations could be observed between societies, they did share some characteristics. First, usually they were voluntary

2 For an overview on Zurich in the 18th century, see: Conrad Ulrich, "Das 18. Jahrhundert," in Geschichte des Kantons Zürich, ed. Niklaus Flüeler and Marianne Flüeler-Grauwiller, vol. 2, Frühe Neuzeit. 16. bis 18. Jahrhundert, (Zurich: Werd, 1996); Clive H. Church and Randolph C. Head, A Concise History of Switzerland (Cambridge, New York: Cambridge University Press, 2013), 104-31.

3 For the history of industrialisation in the Zurich countryside, see: Rudolf Braun, Industrialisation and Everyday Life, trans. Sarah Hanbury Tenison (Cambridge, New York: Cambridge University Press, 199o). 
associations of citizens; secondly, their activities pursued reform-oriented targets. In Zurich, this movement was especially important; so much, so that at least 23 societies had been founded by the end of the century. ${ }^{4}$ One of the most remarkable was indeed the "Physical Society," the main subject of this article.

The Zurich Physical Society (Physikalische Gesellschaft, later called Naturforschende Gesellschaft) was established in 1746 by some citizens associated with Dr Johannes Gessner (1709-1790), professor of "physicesque mathesos" at the "Carolinum," Zurich's theological academy. ${ }^{5}$ All of them were interested in "physics," the name by which natural sciences were known in those days. What drove them to create a society was their regret that, in their city, no institution existed to promote this field of learning, which was becoming increasingly important in the 18 th century. The "solution" chosen by the Zurichers, the establishment of a specialized learned association was, as already mentioned, quite a typical in the Age of Enlightenment. ${ }^{6}$

The famous "Royal Societies" of London, Paris and Berlin were used as a model. The founding members expressly set out to imitate these distinguished forerunners, but on a much humbler level, adjusted to their own, limited capacities. In contrast to the celebrated paragons, original research was not the main criterion or objective of the Zurich society's activities. Its main purpose was closer to what today we would call adult education, conceptualised as an agent for making new scientific findings, and especially "useful" applications of this knowledge, accessible to Zurich's burghers. ${ }^{7}$

4 Emil Erne, Die schweizerischen Sozietäten: Lexikalische Darstellung der Reformgesellschaften des 18. Jahrhunderts in der Schweiz (Zurich: Chronos, 1988), 65-157.

5 The only treatise on this society available in English is James Roger Hansen, Scientific Fellowship in a Swiss Community Enlightenment: A History of Zurich's Physical Society, 17461798 (Columbus: Ohio State University, 1981).

6 James E. McClellan III, Science Reorganized. Scientific Societies in the Eighteenth Century (New York: Columbia University Press, 1985); Henry E. Lowood, Patriotism, Profit, and the Promotion of Science in the German Enlightenment: The Economic Scientific Societies 1760-1815 (New York, London: Garland Pub., 1991).

7 According to the statutes, the Society's purpose was the advancement of "the knowledge of nature, insofar as it serves the comfort, utility, and necessity of human society in general, and especially of our dear fatherland." StAZ B IX 208, Erster Ursprung der Naturforschenden Gesellschaft in Zürich, Gesetze und Uebungen derselben, wie sie nun in dem Jahr 1776 geordnet und bestäthet sind, und auch für die folgenden Zeiten dienen sollen (the original 1746 document is lost). 
The society was principally open to any burgher who could afford the membership fee. Its active members included medical doctors, who played an important role, but also pastors, some merchants, and a few artisans. Similar to the "Royal Societies," there was also a class of honorary members who were not obliged to take an active part, but served as patrons, ensuring that the society was anchored in the circles of the urban elites. ${ }^{8}$

From the very beginning, the Society began to build up its basic infrastructure, namely a library and collections of "naturalia" and scientific instruments. Every second week, and later every week, its members met to attend lectures on a wide variety of scientific subjects - the protocols mention nearly all topics of 18th-century "physics," from botanical and zoological classification to electricity - and presentations of strange "naturalia" or "monsters," which in those days would be classified as natural history. During the first decade of its existence, the Society's meetings were dominated by rather abstract subjects, while applied sciences played a minor role. This changed when, in 1759, a specialised "economic" commission was established, with the remit to focus on collecting, testing and disseminating "useful" knowledge related to agriculture.

The inspiration for widening their scope and promoting practical applications seems to have come from Bern; there, an "Economic Society" with a comparable objective had just been founded. ${ }^{9}$ The Bern "Society" had itself been inspired by similar associations established elsewhere in Europe, which made it part of a larger movement. It was a time when elites began to develop a keen interest in agriculture; States and princes as well as private associations debated over agricultural reform programmes and tried to put them into practice. As a result, the second half of the century became the heyday of a particular type of association, the agricultural or "economic" societies. ${ }^{10}$ Together with the Bernese society, Zurich's Economic Commission was one of the first of this kind in German-speaking Europe.

The Society's as well as the Economic Commission's activities generated very rich records, which are largely extant, preserved and now stored in the State Archives of Zurich (StAZ); they constitute the empirical basis for this study.

8 For the Society's organisational structure, see: StAZ B IX 208.

9 For this society, see: Regula Wyss and Martin Stuber, "Paternalism and Agricultural Reform: The Economic Society of Bern in the Eighteenth Century," in The Rise of Economic Societies in the Eighteenth Century, ed. Koen Stapelbroek and Jani Marjanen (Basingstoke: Palgrave Macmillan, 2012).

10 For an overview, see: Koen Stapelbroek and Jani Marjanen, "Political Economy, Patriotism and the Rise of Societies," in The Rise of Economic Societies in the Eighteenth Century, ed. Koen Stapelbroek and Jani Marjanen, (Basingstoke: Palgrave Macmillan, 2012) and the case studies in the same volume. 


\section{Demographic Surveys: Motivation and Theoretical Orientation}

In the political discourse of that time, population was seen not only as the most important element of a state's economic and military strength, but also as an indicator of the government's ability to care for its subjects. To the contemporary eye, a growing population was infallible proof of the goodness of the authorities, and therefore of their legitimacy. ${ }^{11}$ So it is not surprising that government administrations more and more often strove to gather information on the number and condition of their subjects. Similarly, interest in what later became known as "demography" was closely followed by growing interest in natural resources in the territory. According to the enlightened reformers' utilitarian worldview, nature provided everything for man's wellbeing - as long as its treasures were sufficiently known; for this was considered to be an essential prerequisite for any profitable exploitation. Increasingly, this sort of survey aimed not just at inventorying, but also at a systematic understanding of a country's political economy, investigating relations of dependency between factors such as farming productivity and population.

Zurich's elite, or at least its reform-friendly minds, were not unaffected by, or indifferent to, these new ideas; they were well informed of actual examples of census that had been undertaken elsewhere, for example in Sweden ${ }^{12}$ or in Prussia. They seem to have been particularly impressed by the case of King Frederick the Great, who, thanks to an excellent knowledge of his territory's population and resources, managed to develop his relatively small country into a remarkable military power. ${ }^{13}$

In the Physical Society, a rallying point for such men, the opinion took hold that their hometown should not neglect these developments and that it might be useful to systematically collect information on the territory's inhabitants and nature. There was hope that this knowledge might help to improve Zurich's economy effectively and reduce its dependence on grain imports.

As the city-state lacked an adequate administrative organization able to perform a census, a complex and time-consuming operation, the Physical Society took on the responsibility for it; this is why Zurich's first censuses were not organised by the State itself, but by a private organization. It needs to be said that its members saw their undertakings as a service to their fatherland;

11 Edward Prince Hutchinson, The Population Debate. The Development of Conflicting Theories up to 1900 (Boston: Houghton Mifflin, 1967), 94-109.

12 The pioneering Swedish censuses became a model for similar projects all over Europe: Peter Sköld, "The Birth of Population Statistics in Sweden," History of the Family 9 (2004).

13 StAZ B IX 244, Johann Heinrich Schinz, Anmerkungen über die Abzehlungen der Einwohner zu Zürich, 1762, 284. 
they clearly emphasized that, far from being merely a way of satisfying their curiosity, these surveys were meant to be useful.

Censuses undoubtedly figure among the Physical Society's most important achievements; they were, at least for the Swiss Confederacy, pioneering; it was not until the early 19th century that the State took on the task to systematically survey its inhabitants. It was a common phenomenon that societies such as this one should develop and launch projects that would later become part of the business of the State.

The Society was well aware of the sensitive nature of its surveys; statistical data meant political power and had therefore to be treated as a state secret. It was probably because the Society's members came from families connected with the government that the authorities tolerated its activities, and even acquiesced to the publication of some of the results. ${ }^{14}$ But in Zurich, too, statistical investigations could, unless executed with the necessary caution, have severe consequences, as the fate of Johann Heinrich Waser (1742-1780) shows. Waser, a pastor by profession and an assiduous member of the Physical Society, was an able and ardent statistician; he was absolutely fascinated by the knowledge-generating potential of numbers. He used the Society as a platform to present his results but did most of his extensive work on his own initiative. Tapping into different types of sources, such as tax registers, recruitment and parish registers, he retraced the development of Zurich's population back to the 15th century and used and drew maps to estimate the canton's surface area. Among his published or manuscript works, we also find treatises about historical changes in wages, grain prices and the value of money, as well as on life or fire insurance. ${ }^{15}$ His confidence in himself and in his findings was such that he went as far as using them to daringly criticise the authorities - which, in those days, could end fatally. In fact, he first lost his job and livelihood and, in the end, was sentenced to death for high treason. ${ }^{16}$

In the 18th century, two or three different methodological approaches for gathering "statistical" information on territories can be distinguished:

14 Christian Simon, "Hintergründe Bevölkerungsstatistischer Erhebungen in Schweizer Städteorten des 18. Jahrhunderts. Zur Geschichte des demographischen Interesses," Schweizerische Zeitschrift für Geschichte 34, no. 2 (1984): 201-04.

15 On Waser's works, see: Albert Hauser, "Johann Heinrich Waser, Leben und Werk eines grossen Volkswirtschaftlers im Zeitalter der Aufklärung," in Festschrift zum 7o. Geburtstag von Eugen Böhler, ed. Schweizerische Gesellschaft für Konjunkturforschung (Zurich: Polygraphischer Verlag, 1963).

16 For an overview of Waser's fate, see especially: Rolf Graber, "Der Waser-Handel. Analyse eines sozipolitischen Konflikts in der Alten Eidgenossenschaft," Schweizerische Zeitschrift für Geschichte 30, no.3/4 (1980). 
the quantitative French and, especially, English tradition - called "political arithmetic" - on the one hand; and the decidedly qualitative and descriptive German "Universitätsstatistik" on the other. ${ }^{17}$ All in all, the Zurich Society combined quantitative and qualitative methods, but had an intriguing interest in numerical procedures. With their readiness to use quantitative methods, the Zurich Society not only stood in contrast to the other important Swiss reform association, the already mentioned "Economic Society" of Bern, ${ }^{18}$ but also differed from most such private reform societies. ${ }^{19}$

References to all the protagonists of the English "political arithmetic," from John Graunt (1620-1674), to William Petty (1623-1687), ${ }^{20}$ Edmond Halley (1656-1742) and Gregory King (1648-1712) can be found in the societies' statistical treatises; and the Zurichers were also familiar with the work of French statisticians such as Antoine Deparcieux (1703-1768), and the Dutch Willem Kersseboom (1691-1771). Astonishingly, however, the Society just marginally adopted the descriptive "Universitätsstatistik". In its library, works by the protagonists of this science - for example the Göttingen professor Gottfried Achenwall (1719-1772), considered to be its founding father ${ }^{21}$ - seem to be completely absent.

The Zuricher's most important theoretical reference was also of "German" origin. It originally had nothing to do with any efforts to gather information to improve statecraft, but was the result of the Prussian pastor Johann Peter Süßmilch's (1707-1767) endeavour to use statistical methods to obtain deeper insights into the principles of the divine world order. He was inspired by "physicotheology," a movement that aimed to unify naturalist research and religion by stating that closer understanding of the structure of creation would lead

17 On these differing traditions of early modern "statistics": Alain Desrosières, Die Politik der grossen Zahlen: Eine Geschichte der statistischen Denkweise (Heidelberg: Springer-Verlag, 2005), 19-35; Karin Johannisson, "Society in Numbers: The Debate over Quantification in 18th-Century Political Economy," in The Quantifying Spirit in the Eighteenth Century, ed. Tore Frängsmyr, John L. Heilbron, and Robin E. Rider (Berkeley: University of California Press, 1990).

18 The Oeconomic Society had set up a comprehensive programme for gathering descriptive data on Bern's territory: Gerrendina Gerber-Visser, Die Ressourcen des Landes: Der ökonomisch-patriotische Blick in den Topographischen Beschreibungen der Oekonomischen Gesellschaft Bern (1759-1855) (Baden: hier + jetzt, 2012).

19 For an overview of the activities of these societies, see Lowood, Patriotism, Profit, and the Promotion of Science in the German Enlightenment.

20 On Graunt and Petty: Mohamed Rassem and Justin Stagl, eds., Geschichte der Staatsbeschreibung: Ausgewählte Quellentexte 1456-1814 (Berlin: Akademie-Verlag, 1994), 271-94.

21 On Achenwall, see: ibid., 399-424. 
to a better knowledge of God himself. ${ }^{22}$ The Göttliche Ordnung (the title of his work, first published in 1742 and followed by a massively enlarged second edition in $1761 / 62$ ) was to become an influential and widely read work, even though the author's physicotheological inspiration was not shared by all of its readers. ${ }^{23}$

In order to gather demographic information necessary for his project, Süßmilch corresponded and collaborated with many researchers across Europe. One of them was President Gessner, and this probably explains why Süßmilch was so well received in Zurich. ${ }^{24}$ Apart from that, Gessner is known to have been a keen mathematician, and his influence undoubtedly was the main reason for the society's theoretical preferences. In 1748, he published a "dissertation" entitled De termino vitae, where he discussed different causes of death alongside with statistical methods to calculate life expectancy. Here, he cited Süßmilch right at the beginning, and he stated that statistics was not only useful for medicine and statecraft, but especially as a means of recognizing the perfection of the Almighty's creation. ${ }^{25}$

Nevertheless, the influence of physicotheology began to fade over the course of the decades. The above-mentioned Waser, a former pupil of Gessner, seems not to have justified his activities in this way - even though he was a pastor! Apart from that, he criticised Süßmilch for not being experienced enough in mathematics. ${ }^{26}$

Another important field of study should be mentioned here for the sake of completeness, without being expanded further: medical statistics. Such efforts were undertaken by the two doctors, Johann Caspar Hirzel, father $\left(1725^{-1803)}\right.$ and son (1751-1817), who succeeded each other in the position of Town Physician. The duties of this official role included being responsible for the city's hospitals, which allowed them to compile comprehensive lists with the causes of deaths of patients that had deceased there. ${ }^{27}$ Here, statistical data was collected with a clear intention to support "improvement": the rate

22 Jean-Marc Rohrbasser, Dieu, l'ordre et le nombre: Théologie physique et dénombrement au XVIII ${ }^{e}$ siècle (Paris: Presses Universitaires de France, 2001).

23 Justus Nipperdey and Patrick Festy, "Johann Peter Süßmilch: de la loi divine à l'intervention humaine." Population 66, no. 3/4 (2011).

24 Herwig Birg, ed., Ursprünge der Demographie in Deutschland: Leben und Werk Johann Peter Süßmilchs (1707-1767) (Frankfurt a.M.: Campus, 1986), 158-59.

25 Johannes Gessner, Dissertatio Physico-Medico-Mathematica de Termino Vitae (Zurich: ex officina Gessneriana, 1748), 28-29.

26 StAZ B X 26.20, Johann Heinrich Waser, Rede von der politischen Rechenkunst, 12.

27 They were also presented to the Society; for example: StAZ B IX 247, Dr Johann Caspar Hirzel Jr., Relation von den merkwürdigsten Vorfällen im Spithal 1783-1788, 96-112; ibid., Ueber Krankheiten aus den Gschaubüchern 1708-1790, 140-76. 
of stillborn children, for example, was seen as an indicator of how well the midwives did their job. The Hirzels also made weather observations and tried to find correspondences between the weather and certain diseases, which was popular in contemporary medical discourse. ${ }^{28}$

Alarming Trends: The Development of Zurich's Population

In 1748, President Gessner encouraged one of the society's members, the "Junker" (squire) Hans Ulrich Blaarer (1717-1793), to prepare a draft for censustables. ${ }^{29}$ In all probability, this was the first time that somewhere in the Old Swiss Confederacy such considerations were made - one year before the pioneering Swedish Tabellverket was launched, the first project to use tables for systematically surveying a country's population. That shows how wellinformed and innovative the Zurichers were, even when they lacked the means to put their plans immediately into practice.

It was not until 1756 that the Society conducted Zurich's first census. By contrast with the aforementioned project, it was limited to the city's population. It proved too complex and time-consuming to extend it to the whole territory, as the Society decided not to rely on parish registers, but to perform its own survey. Moreover, Blaarer's forms were found to be too detailed, as were other proposals, for example a scheme developed by the English Royal Society. Instead, the Society chose quite a simple scheme, devised by the French engineer Sébastien Le Prestre de Vauban (1633-1707). ${ }^{30}$ This scheme counted the inhabitants of a village per household, and only contained the categories house-father and house-mother, adult or minor children and servants; the Zurichers added two extra columns for boarders ("Tischgänger"), meaning people living as paying guests in a family - for example students from other cities - and journeymen, as they were common in the households of artisans. ${ }^{31}$

28 On medical meteorology and statistics in France and England: Andrea A. Rusnock, Vital Accounts (Cambridge, New York: Cambridge University Press, 2002), 109-36.

29 The Society was well aware of the pioneering character of these tables; even over a decade later, it thought them worth publishing: Johann Ulrich Blaarer, "Entwurf Allgemeiner Politischer Gemeind-Tafeln," Abhandlungen der Naturforschenden Gesellschaft in Zürich 2 (Zurich: Heidegger und Compagnie, 1764).

30 Vauban's project (not implemented) was designed to quantify the total population of the French Kingdom: [Sébastien Le Prestre de Vauban], Projet d'une Dixme Royale ([Rouen], 1707); for a discussion, see Michèle Virol, "Connaître et accroître les peuples du royaume: Vauban et la population," Population 56, no. 5 (2001).

31 StAZ B IX 85, Volkszählungen in der Stadt Zürich 178o und 179 o. 
Only in some cases, but not systematically, the housefather's profession was mentioned. The census seems not to have been intended as a survey of the city's socio-economic condition - at least at the beginning. On the other hand, the distinction between burghers and non-burghers was a very important criterion: people without this status were marked in red and counted separately. As no protocols have been handed down, we know scarcely anything concerning the discussions surrounding the creation of the first census-tables; but there is little doubt that, as far as the city was concerned, the burgher-population must have occupied centre state in the Society's interests. Given the Society's social structure, this is not at all surprising; as members of the ruling class, the associates had to be concerned about changes in the ratio of their own caste and the subordinate classes. This was an important issue in order to secure political power.

For the purpose of counting, the city was divided into eleven districts, and volunteers were given two weeks' time to register every household in their area according to this prescribed scheme. Their lists were then collected, revised to eliminate errors, and finally copied into a folio volume. ${ }^{32}$ These results were then presented to the society. According to this first, more or less reliable, census, about 11,0oo people were living in Zurich, a much lower number than had been assumed until then. Some estimates went up to 20,00o people, while a careful calculation based on parish registers by President Gessner some years earlier had resulted in 12,500 inhabitants. ${ }^{33}$

The census was repeated in $1762,1769,1780$, and 1790 , with slightly modified tables. ${ }^{34}$ In order to assure the uniformity and reliability of the results, a lot of details on how to complete the tables had to be prescribed; and each time, these explanations became slightly more sophisticated. For example, people staying there only on workdays - say, workers in manufactories - should be ignored. A "household" was defined as "people having their meals together."

At the beginning, the few maidservants being burghers were simply counted as daughters of their employers, as the society found it more important to identify "foreign" people than to adequately register the families. It was not until 1780 that widowers and widows were distinguished as a separate status from married.

From the second cycle onwards, pre-printed tables facilitated the work; in the same year, the member Johann Heinrich Schinz (1727-1792) took the

32 StAZ B IX 10, Volkszählung in der Stadt Zürich $175^{6}$.

33 StAZ B IX 244, Johann Heinrich Schinz, Anmerkungen über die abzählungen der Einwohner zu Zürich in den Jahren 1756 und 1762, 294.

The results were recorded in five volumes: StAZ B IX 10-14. 
initiative and supplemented the Society's tables with excerpts from the guilds' registers in order to provide an overview of the occupational structure of the burghers and to check whether there might be an oversupply of certain crafts. As every burgher had to belong to a guild, including pastors and bailiffs living outside the city, this was also a means of determining their total number.

Apart from several technical difficulties, the Society had to cope with, at least in its early stages, some resistance from the population - even when the lack of sources makes it difficult to reconstruct how pronounced this had really been. The Society's reports mentioned two types of anxiety affecting people: first, religious qualms based on the biblical narration of the divine punishment that King David's census received; secondly, a rumour that it might be preparatory work for raising taxes. ${ }^{35}$ It was quite common at the time for censuses to raise exactly such fears - and it is no less true that concerns about taxes were not always groundless.

From the second census onwards, the Society tried to analyse and compare the figures assembled in the tables. Three essays give us some insights on how changes in urban population were interpreted. ${ }^{36}$ Despite the aforementioned difficulties, the Society was able to detect some changes in the number and structure of the city population. And these had, at least from its members' perspective, an alarming trend: the constant decrease in the number of inhabitants with burgher status. The society was quick in finding an answer to the question why this was happening. Changing customs, increasing laziness as well as a growing love for lavishness and "luxury" among young people - which would prevent them from marrying and founding families - were thought to be the reasons. ${ }^{37}$ To blame any societal or economic difficulties on people's idleness was very typical of the time..$^{38}$

Apart from that, the censuses revealed a striking anomaly, namely that, contrary to the rule that there were usually more newborn boys than girls, in

35 StAZ B IX 248, Johann Rudolf Schinz: Geschichte der von Physik. Gesellschaft in Zürich aufgenommenen Zählung der Einwohner der Stadt. Der Gesellschaft vorgelesen den 12.11.1781, 156 .

36 StAZ B IX 244, Johann Heinrich Schinz, Anmerkungen über die Abzählungen der Einwohner zu Zürich in den Jahren 1756 und 1762, 282-320; StAZ B IX 248, Johann Rudolf Schinz: Geschichte der von Physik. Gesellschaft in Zürich aufgenommenen Zählung der Einwohner der Stadt. Der Gesellschaft vorgelesen den 12.11.1781, 156-71; B IX 249, Johann Jacob Pestalutz, Ueber die Volkszählung der Stadt Zürich im Jenner 179o, 16o-87.

37 They especially blamed the imitation of French fashion in clothing and giving dinners: StAZ B IX 248, Johann Rudolf Schinz: Geschichte der von Physik. Gesellschaft in Zürich aufgenommenen Zählung der Einwohner der Stadt. Der Gesellschaft vorgelesen den 12.11.1781, 169-70.

38 Rusnock, Vital Accounts, 180. 
Zurich, the male/female ratio was almost equal. This is particularly interesting, as the relative constancy of this ratio, which had been observed in the 17th century already, was considered to be proof of divine providence.$^{39}$ For this "aberrance," however, the Society's members had simply no explanation; neither did they want to speculate on possible consequences. ${ }^{40}$

The results were not only a shrinking urban population, but also a slowly growing proportion of non-burghers, for instance servants. According to the Society's census, at end of the 18th century about $20 \%$ of the city's inhabitants were domestic servants, most of them female. ${ }^{41}$ Of course, a certain number of servants was accepted as indispensable, a necessary evil in a sense; but the censuses showed an increasing number of menservants, which claimed higher wages than maids and were therefore seen as the sign of a baneful predilection for luxury; in the same way, the growing proportion of maids from outside the Canton were feared to be a threat to local customs. ${ }^{42}$ However, the foremost problem was not these foreigners integrated in families, but the growing number of non-burgher households, called "Hintersassen."43 They were not only disliked as undesirable competitors of burgher craftsmen, but also seen as a potential burden to the city's poor relief institutions and, probably worst of all, as political rebels. A frightening negative example the Zurichers knew of was Geneva; this city had a considerable proportion of inhabitants excluded from political participation, and during the 18th century, they had expressed their discontent in several riots. ${ }^{44}$ Nevertheless, the situation in Zurich was quite different, as the "Hintersassen" never made up more than $10 \%$ of all households. The seemingly simple solution of naturalizing some of the "Hintersassen" was refused by the urban elite, including the relatively reform-oriented members of the Physical Society - until the end of the old regime. In the late 17th century already, the acceptance of new burghers had almost completely stopped, as was the case of other cities in the Old Swiss Confederacy as well as in the Holy Roman Empire. The ruling families, even when their number steadily dropped, did not want to share their privileges with anyone who could not look back on a generations-old history of burgher ancestors.

\footnotetext{
39 Ibid., 171.

40 StAZ B IX 249, Johann Jacob Pestalutz, Ueber die Volkszählung der Stadt Zürich im Jenner 1790, 179 .

41 Ibid., 170.

42 StAZ B IX 248, Johann Rudolf Schinz: Geschichte der von Physik. Gesellschaft in Zürich aufgenommenen Zählung der Einwohner der Stadt. Der Gesellschaft vorgelesen den 12.11.1781, 164-65.

43 Ibid., 168.

44 Church and Head, A Concise History of Switzerland, 108-09.
} 
The changes in the urban burgher population contrasted clearly with the countryside, where the population, apart from a sharp decline caused by the famine of the early 1770s, was constantly expanding. Although it remained difficult to calculate exactly the Canton's total inhabitants, Zurich's elites were well aware of that. In 1763, President Gessner, using church registers, estimated Zurich's population at 150 ,ooo people. ${ }^{45}$ The famine of the 1770 os also prompted the authorities to find out more about food supply in the territory. In 1771, the government "Kornkammer" (grain administration) gathered information on the population of each village, and on its grain production, estimated from the tithe. It is not clear in what way the Society was involved there, but later on its findings were also discussed in the Economic Commission.

Also, from then onwards, on a yearly basis, Dr Johann Caspar Hirzel presented baptisms and deaths of the past year, which he was able to obtain from registers assembled by the church synod, a council of Zurich's pastors. Hirzel also compared these figures to neighbouring territories and could proudly conclude that mortality was lower in his homeland than anywhere else. ${ }^{46}$

Hirzel and probably most of the Economic Commission were convinced of the positive significance of a growing population; the more people, the greater the supply of "working hands," the precondition for a prosperous country. Another member of the Society, pastor Waser, was rather more critical and emphasized that this would only be valid as long as population growth did not exceed farming productivity. ${ }^{47}$ But all agreed on the importance of promoting agriculture. From 1759 onwards, this was to become the endeavour of the Economic Commission.

\section{$5 \quad$ Prerequisite for Reforms: Knowing the Territory}

At one of their first meetings, the members of the Economic Commission stated that comprehensive knowledge of the territory would be an absolutely essential prerequisite for planning and implementing any reforms, especially for "improving" agriculture. Therefore, they laid down that collecting information should be their commission's primary line of action. Implementing such reforms was considered a task exceeding the scope of a private society, but

45 StAZ B IX 181, Tagbuch der Naturforschenden Gesellschaft 3, meeting of 5 September 1763, 18-19.

46 StAZ B IX 59, Protokoll der Oekonomischen Kommission 2, meeting of 9 May 1772, 195.

47 StAZ B X 27.29, Johann Heinrich Waser, Bevölkerung, Sterblichkeit. 
they hoped to persuade the government to establish a specialized reform committee, which then could base its efforts on the preparatory work done by the Economic Commission. ${ }^{48}$ This plan was finally successful: two decades later, in 1779 , the authorities actually established a "Landwirtschaftskommission" (Commission for agriculture). Members of the Economic Commission came to play an important role there. In one of its first meetings, the "Landwirtschaftskommission" decided to gather documents and tables from both the State Archives and those of the Physical Society. ${ }^{49}$

Accordingly, the Society must have been in possession of a considerable stock of information on the Canton's agriculture until then. This raises the question how the Society had managed to collect all this knowledge.

Information reached the Commission through several channels. It was in close contact with several men from the countryside, especially pastors, who supported their reformist agenda. From them, the Commission received, every now and then, more or less detailed descriptions of certain regions. In addition, some of its members undertook journeys all around the Canton and recorded their observations in travel journals. These contributions were discussed in the Commission's meetings and usually, copies of the manuscripts were archived.

Information collected systematically played an even more important role. To do so, the Economic Commission had used a set of different tools and techniques, some of them traditional, others quite innovative. As for demography, quantification was important, but the Commission also began to be interested in rather descriptive cameralist methods. An example of this was a treatise by Carolus Linnaeus on the usefulness of travelling in the homeland, that was read and discussed in a meeting. ${ }^{50}$

The basic and most important tools were tables and questionnaires. Applying methods similar to those used to conduct city censuses, a village's inhabitants were counted by the households they belonged to. In addition, details of their land ownership as well as of the livestock they kept were collected as well. Interestingly, some years later, the Commission's members began to consider the numerical data gathered by means of the tables as insufficient,

48 StAZ B IX 58, Protokoll der Oekonomischen Kommission 1, meeting of 21st February 1759, 7 .

49 StAZ B III 155, Protokoll der Landwirtschaftlichen Commission 1, meeting of 28th April 1779, 1.

5O StAZ B IX 183, Tagbuch der Naturforschenden Gesellschaft 5, meeting of 27th February 1769, 25 . 
and introduced "qualitative" questionnaires to complement this information. ${ }^{51}$ In 82 detailed questions, aggregated in ten groups, information concerning the buildings in a village, the exact use and condition of different kinds of land pastures, fields, commons and forests - as well as details of cattle, horses and small livestock had to be given. These tables and questionnaires, although they do not exist for every village, today are an important source for reconstructing Zurich's economic history. ${ }^{52}$ From 1762 onwards, usually once or twice a year, a couple of them were sent to the pastors of some villages; the clergyman had to fill them in; afterwards, farmers from these villages were invited to the city in order to discuss some details. These meetings, called "Bauerngespräche" (conversations with farmers), were unusual - to many contemporaries, urban gentlemen and simple farmers talking together seemed to be a daring way of overstepping class barriers. But, needless to say, the commission took care not to upset the traditional hierarchy; so that farmers were not allowed to talk as they felt like, but only to answer questions. ${ }^{53}$ Nonetheless, although it is rather debatable how much "Bauerngespräche" effectively contributed to an actual exchange of information, they were a clear sign that members of the urban elite had begun to give credit to their rural subjects for possessing potentially relevant and useful knowledge.

The Commission was interested not only in the number of the Canton's inhabitants and the condition of Zurich's fields and forests, but also in the everyday work of farmers. To get hold of this information, concerning problems that many of the urban members were not so familiar with, the Commission resorted to prize competitions. Admittedly, such competitions were quite a common way used by reform societies to reach out to a broader audience. Yet, the way the Economic Commission adapted them to its own purposes was particular. Whereas, usually, such questions were intended to be answered by well-educated men, the Zurichers' questions were directly addressed to local farmers and asked them questions about their everyday work in a very detailed manner. Between 1762 and 1803 , a total of 48 questions were advertised,

51 StAZ B IX 47a, Kurze Instruction oder Anleitung, vor Diejenige, so den ökonomischen Zustand [...], in die von Lobl. Physikalischer Gesellschaft in Zürich gedruckten Tabellen eintragen wollen.

52 StAZ B IX, 86-91, Oekonomische Tabellen, 1762-1789; for a comprehensive analysis of this material, see: Ulrich Pfister, Die Zürcher Fabriques. Protoindustrielles Wachstum vom 16. zum 18. Jahrhundert (Zurich: Chronos-Verlag, 1992).

53 For a critical discussion of the "Bauerngespräche", see Rolf Graber, "Die Züricher Bauerngespräche: Innovation der Volksaufklärung oder Instrument der Herrschaftssicherung?" in Die Entdeckung von Volk, Erziehung und Ökonomie im europäischen Netzwerk der Aufklärung, ed. Holger Böning, Werner Greiling, and Reinhart Siegert (Bremen: edition lumière, 2011). 
covering subjects from forestry, to so-called "artificial meadows," 54 from potato crops, to the drainage of wetlands, winegrowing, and livestock.

The number and quality of the answers differed from year to year, reaching from just five participants up to more than $30 .{ }^{55}$ Even when there were a handful of very interested farmers who seem to have participated on their own initiative, one can observe that often, the village's pastor's commitment played an important role whether farmers were involved or not.

Thanks to these questions, over the years, the Commission gathered a lot of information on farming practices - and their diversity throughout the Canton. This knowledge did not remain in the society's archives, but was compiled into manuals, which were later distributed among the farmers. ${ }^{56}$

We know relatively little about how the Society processed and interpreted the material collected; this observation, incidentally, is valid also for many other states and institutions that were collecting "statistical" data in that period. Besides political concerns - "false" interpretations might lead to trouble with the authorities - the eschewal of detailed evaluations was often simply due to the lack of skills for processing the data, or the incompleteness of the information collected. Tables were undoubtedly an important invention for securing uniformity of information, but they could not absolutely guarantee it. This was especially the case when data collecting was not performed by a small group of well-trained men; therefore, the ways in which the Oeconomische Tabellen were completed varies from village to village - in contrast to the much more systematic city census tables.

The most sophisticated efforts to evaluate the data were not undertaken by the Society as such, but by some dedicated members on their own. A very comprehensive attempt to make sense of the Commission's data was Dr Johann Caspar Hirzels's 1788 treatise entitled Beantwortung der Frage: Ist die Handelschaft, $[. .$.$] unserem Lande schädlich oder nützlich [\ldots]^{57}$ [Answering the question: Is commerce useful for our country or not?]. In this essay, Hirzel used

54 On this subject, see Sarah Baumgartner, 'Nützliche Gras-Arten und Kräuter.' Die Zürcher Ökonomische Kommission und das Wissen vom Klee- und Wiesenbau," in Wer das Gras wachsen hört. Wissensgeschichte(n) der pflanzlichen Ressourcen vom Mittelalter bis ins 20. Jahrhundert, ed. Simona Boscani Leoni and Martin Stuber, Jahrbuch für Geschichte des ländlichen Raumes 14 (Innsbruck: Studien-Verlag, 2017).

55 A considerable proportion of them, more than 500 items, can still be consulted: StAZ B IX 18-24, Preisabhandlungen von Landleuten, 1762-1784.

$5^{6}$ Even when their titles always begin with "Anleitung für die Landleute" [Instructions for Farmers], they were often read by urban agronomists or pastors rather than farmers.

57 Johann Caspar Hirzel, Beantwortung der Frage: Ist die Handelschaft, wie solche bey uns beschaffen, unserm Lande schädlich oder nützlich in Absicht auf den Feldbau und die Sitten des Volkes? ([Zurich], 1788). 
statistical data collected by the Commission, but also a good deal of information that he had gathered on his walks through the Canton to assess the effects of the putting-out industry on the Canton's agriculture. The treatise reveals a new view of the territory. For example, Hirzel introduces an innovative subdivision of the Canton, following agro-ecological criteria, not the political subdivision in bailiwicks. Even when he complained that some probably important information was still wanting, he was able to give a detailed assessment on how the impact of industry differed from region to region. Whereas, with regard to corn producing regions in the lowlands, the concern that it was taking away workforce from agricultural occupations could be confirmed, Hirzel showed that the impact of industry on mountainous regions was rather positive. Here, the additional source of income enabled people to care better for their fields and, in addition, offered a chance of employment during the winter.

Around the middle of the 18th century, the members of the reform-oriented Zurich Physical Society, inspired by the discourse in the literature, began to deliberate on how to gather information for a better knowledge of the citystate's territory. At first, their activities seem to be motivated by rather theoretical "scientific" interests, where physicotheological ideas played an important role. Subsequently, however, the society began to collect information, towards a more vigorous support of practical improvement in agriculture. A broad range of authors on these subjects seem to have been familiar to the Zurichers - at least nominally, as only a few of the members were able to really delve in statistical methods and problems. To achieve its goals, the Society tested and combined different techniques and sources of information, qualitative as well as quantitative. The Society conducted its own surveys, but it also relied on older records, such as Church registers, which it used for its own new purposes. The intention to use data for analysing economic or social issues in order to implement reforms distinguishes the Society's surveys from traditional data collections by the Church or the State, which was always done for specific, limited purposes, for example raising taxes. They not only tried to adapt methods from the contemporary discourse, but also devised innovative approaches for getting in contact with the rural population, like the "Bauerngespräche".

The perspectives were equally diverse; on the one hand, there was a "rational" interest in understanding the Canton's economic system and its inhabitants' productivity, but traditional criteria for categorizing people remained 
important - as the city-census' emphasis on the distinction between burghers and non-burghers shows. It is also interesting to see how the application of systematic and quantitative methods resulted in the discovery of the territory's actual diversity. The Physical Society's records are an interesting source for modern historians, but it is difficult to reconstruct what conclusions the contemporaries drew from this material. This would not be unusual, since typically, at the time, quite impressive records were collected, but then no appropriate means were available for processing them. Institutionalization also was in its infancy. Even though the Society and its Economic Commission took on certain tasks, the personal initiative of several members remained crucial, as the examples of Hirzel's and Waser's work shows. The Society already collaborated with the authorities, but it was not until the 19th century that statistical surveys became part of the State's obligations.

\section{Acknowledgements}

This contribution is based on research funded by the Swiss National Science Foundation and carried out in the context of the project "Kulturen der Naturforschung" (Cultures of Natural History), Project-Nr. 144731, led by Simona Boscani Leoni at the University of Bern (Switzerland) from 2014-2018.

\section{Bibliography}

\section{Manuscripts}

StAZ (Staatsarchiv Zurich) B III 155, Protocoll der Landwirtschaftlichen Commission 1, meeting of 28 April 1779, 1.

StAZ B IX 10, Volkszählung in der Stadt Zürich 1756.

StAZ B IX 18-24, Preisabhandlungen von Landleuten, 1762-1784.

StAZ B IX 47a, Kurze Instruction oder Anleitung, vor Diejenige, so den ökonomischen

Zustand [...], in die von Lobl. Physikalischer Gesellschaft in Zürich gedruckten Tabellen eintragen wollen.

StAZ B IX 58, Protokoll der Oekonomischen Kommission 1, meeting of 21 February $1759,7$.

StAZ B IX 59, Protokoll der Oekonomischen Kommission 2, meeting of 9 May 1772, 195. StAZ B IX 85, Volkszählungen in der Stadt Zürich 1780 und 179o.

StAZ B IX 86-91, Oekonomische Tabellen, 1762-1789.

StAZ B IX 181, Tagbuch der Naturforschenden Gesellschaft Zürich 3, meeting of 5 September $1763,18-9$. 
StAZ B IX 183, Tagbuch der Naturforschenden Gesellschaft Zürich 5, meeting of 27 February 1769, 25.

StAZ B IX 208, Erster Ursprung der Naturforschenden Gesellschaft in Zürich, Gesetze und Uebungen derselben, wie sie nun in dem Jahr 1776 geordnet und bestäthet sind, und auch für die folgenden Zeiten dienen sollen.

StAZ B IX 244, Johann Heinrich Schinz, Anmerkungen über die Abzählungen der Einwohner zu Zürich in den Jahren 1756 und 1762, 282-320.

StAZ B IX 248, Johann Rudolf Schinz: Geschichte der von Physik. Gesellschaft in Zürich aufgenommenen Zählung der Einwohner der Stadt. Der Gesellschaft vorgelesen den 12.11.1781, 156-71.

StAZ B IX 249, Johann Jacob Pestalutz, Ueber die Volkszählung der Stadt Zürich im Jenner 1790, 16o-87.

StAZ B IX 247, Dr. Johann Caspar Hirzel jun., Relation von den merkwürdigsten Vorfällen im Spithal 1783-1788, 96-112; ibid., Ueber Krankheiten aus den Gschaubüchern 1708-1790, 140-76.

StAZ B X 26.20, Johann Heinrich Waser, Rede von der politischen Rechenkunst.

StAZ B X 27.29, Johann Heinrich Waser, Bevölkerung, Sterblichkeit.

\section{Printed Sources}

[Vauban, Sébastien Le Prestre de]. Projet d'une Dixme Royale. [Rouen], 1707.

Blaarer, Johann Ulrich. "Entwurf Allgemeiner Politischer Gemeind-Tafeln.” Abhandlungen der Naturforschenden Gesellschaft in Zürich 2 (Zurich: Heidegger und Compagnie, 1764): 277-308.

Gessner, Johannes. Dissertatio Physico-Medico-Mathematica de Termino Vitae. Zurich: ex officina Gessneriana, 1748.

Hirzel, Johann Caspar. Beantwortung der Frage: Ist die Handelschaft, wie solche bey uns beschaffen, unserm Lande schädlich oder nützlich in Absicht auf den Feldbau und die Sitten des Volkes? [Zurich], 1788.

\section{Literature}

Baumgartner, Sarah. “Nützliche Gras-Arten und Kräuter.' Die Zürcher Ökonomische Kommission und das Wissen vom Klee- und Wiesenbau." In Wer das Gras wachsen hört. Wissensgeschichte(n) der pflanzlichen Ressourcen vom Mittelalter bis ins 20. Jahrhundert, edited by Simona Boscani Leoni and Martin Stuber, 81-95. Jahrbuch für Geschichte des ländlichen Raumes 14. Innsbruck: Studien-Verlag, 2017.

Birg, Herwig, ed. Ursprünge der Demographie in Deutschland: Leben und Werk Johann Peter Süßmilchs (1707-1767). Frankfurt am Main: Campus, 1986.

Braun, Rudolf. Industrialisation and Everyday Life. Translated by Sarah Hanbury Tenison. Cambridge, New York: Cambridge University Press, 1990. 
Church, Clive H. and Randolph C. Head. A Concise History of Switzerland. Cambridge, New York: Cambridge University Press, 2013.

Cooper, Alix. Inventing the Indigenous: Local Knowledge and Natural History in Early Modern Europe. Cambridge, New York: Cambridge University Press, 2007.

Desrosières, Alain. Die Politik der grossen Zahlen: Eine Geschichte der statistischen Denkweise. Heidelberg: Springer-Verlag, 2005.

Erne, Emil. Die schweizerischen Sozietäten: Lexikalische Darstellung der Reformgesellschaften des 18. Jahrhunderts in der Schweiz. Zurich: Chronos, 1988.

Gerber-Visser, Gerrendina. Die Ressourcen des Landes: Der ökonomisch-patriotische Blick in den Topographischen Beschreibungen der Oekonomischen Gesellschaft Bern (1759-1855). Archiv des historischen Vereins des Kantons Bern 89. Baden: hier + jetzt, 2012.

Graber, Rolf. "Der Waser-Handel. Analyse eines soziopolitischen Konflikts in der Alten Eidgenossenschaft." Schweizerische Zeitschrift für Geschichte 30, no. 3/4 (1980): 321-56.

Graber, Rolf. "Die Züricher Bauerngespräche: Innovation der Volksaufklärung oder Instrument der Herrschaftssicherung?" In Die Entdeckung von Volk, Erziehung und Ökonomie im europäischen Netzwerk der Aufklärung, edited by Holger Böning, Werner Greiling, and Reinhart Siegert, 43-58. Philantropismus und populäre Aufklärung - Studien und Dokumente 1. Bremen: edition lumière, 2011.

Hansen, James Roger. Scientific Fellowship in a Swiss Community Enlightenment: A History of Zurich's Physical Society, 1746-1798. Columbus: Ohio State University, 1981.

Hauser, Albert. "Johann Heinrich Waser, Leben und Werk eines grossen Volkswirtschaftlers im Zeitalter der Aufklärung." In Festschrift zum 70. Geburtstag von Eugen Böhler, edited by Schweizerische Gesellschaft für Konjunkturforschung, 43-58. Zurich: Polygraphischer Verlag, 1963.

Hutchinson, Edward Prince The Population Debate. The Development of Conflicting Theories up to 19oo. Boston: Houghton Mifflin, 1967.

Johannisson, Karin. "Society in Numbers: The Debate over Quantification in 18thCentury Political Economy." In The Quantifying Spirit in the Eighteenth Century, edited by Tore Frängsmyr, John L. Heilbron, and Robin E. Rider, 343-62. Berkeley: University of California Press, 1990.

Lowood, Henry E. Patriotism, Profit, and the Promotion of Science in the German Enlightenment: The Economic Scientific Societies 1760-1815. New York, London: Garland Pub., 1991.

McClellan III, James E. Science Reorganized. Scientific Societies in the Eighteenth Century. New York: Columbia University Press, 1985.

Nipperdey, Justus and Patrick Festy. "Johann Peter Süßmilch: de la loi divine à l'intervention humaine." Population 66, no. 3/4 (2011): 699-716. 
Pfister, Ulrich. Die Zürcher Fabriques. Protoindustrielles Wachstum vom 16. zum 18. Jahrhundert. Zurich: Chronos-Verlag, 1992.

Rassem, Mohamed and Justin Stagl, eds. Geschichte der Staatsbeschreibung: Ausgewählte Quellentexte 1456-1814. Berlin: Akademie-Verlag, 1994.

Rohrbasser, Jean-Marc. Dieu, l'ordre et le nombre: Théologie physique et dénombrement au XVIII ${ }^{e}$ siècle. Paris: Presses Universitaires de France, 2001.

Rusnock, Andrea A. Vital Accounts. Cambridge, New York: Cambridge University Press, 2002.

Simon, Christian. "Hintergründe Bevölkerungsstatistischer Erhebungen in Schweizer Städteorten des 18. Jahrhunderts. Zur Geschichte des demographischen Interesses." Schweizerische Zeitschrift für Geschichte 34, no. 2 (1984): 186-205.

Sköld, Peter. "The Birth of Population Statistics in Sweden." History of the Family 9 (2004): $5^{-21 .}$

Stapelbroek, Koen and Jani Marjanen. "Political Economy, Patriotism and the Rise of Societies." In The Rise of Economic Societies in the Eighteenth Century, edited by Koen Stapelbroek and Jani Marjanen, 1-25. Basingstoke: Palgrave Macmillan, 2012.

Ulrich, Conrad. “Das 18. Jahrhundert.” In Geschichte des Kantons Zürich, edited by Niklaus Flüeler and Marianne Flüeler-Grauwiller, vol. 2, Frühe Neuzeit. 16. bis 18. Jahrhundert, 364-511. Zurich: Werd, 1996.

Virol, Michèle. "Connaître et accroître les peuples du royaume: Vauban et la population." Population 56, no. 5 (2001): 845-75.

Wyss, Regula, and Martin Stuber. "Paternalism and Agricultural Reform: The Economic Society of Bern in the Eighteenth Century." In The Rise of Economic Societies in the Eighteenth Century, edited by Koen Stapelbroek and Jani Marjanen, 157-81, Basingstoke: Palgrave Macmillan, 2012. 